\title{
Why Does Bundled Product in Telecommunication Service Market Matter?: Evidence from South Korea
}

\author{
Kyungbok Kim ${ }^{1}$, Jeongil Choi ${ }^{2}$ and Sang-Myung Lee ${ }^{3 *}$ \\ ${ }^{1}$ Department of Economics, Auburn University, Auburn, Alabama, U.S.A. \\ ${ }^{2}$ School of Business Administration, Soongsil University, Seoul, South Korea \\ ${ }^{3}$ School of business, Hanyang University, Seoul, South Korea \\ ${ }^{1}$ kzk0056@auburn.edu, ${ }^{2}$ jichoi@ssu.ac.kr, ${ }^{3}$ sanglee@hanyang.ac.kr
}

\begin{abstract}
Due to network effects and market power with bundled product of telecommunication service market, service providers have to differentiate their product group in the competitive market. We explore that installed base(i.e., customer network), and a relationship between single and bundled products do affect corporate performance as well as a dominant transition of bundling market. We empirically describe these issues with data of which each net growth of single and multiple products(=bundled) was gathered by real industry of South Korea where there is overheated competition on their oligopoly market. We found strong evidences that through network effects, not only installed base was significantly associated with corporate finance such as total sales, total assets, and EBITDA, but also the difference between product types and size of installed base in single and multiple products was significant in a competitive market. As a result, our evidence provides an important explanation with operating firms currently. Furthermore, it was clear that using resource-based and market power view specifically vindicated the influences as we hypothesized.
\end{abstract}

Keywords: Telecommunications Service Market, Bundled Products, Network Externality, Market Power, Non-Competitive and Competitive Market

\section{Introduction}

The world telecom operators have endeavored to find the breakthrough in their fields and have made the most of convergence products as the new growth engine in telecommunication service market due to market bloom with all kinds of its services such as broadband, mobile, fixed-line, IPTV, voice, etc.. Telecommunication industry's revenues in the world underwent the remarkable decline in 2009 but stabilized in 2010 and rebounded in 2011. This situation can be ascribed to the strength of mobile communication markets and specifically to the rapid increase within smartphone penetration during this period(OECD, 2013). Following many changes from competition paradigm of telecommunication service market like an introduction of the smartphone, which is the primacy as one of the new growth engines in the ICT industry since late 2000 , service providers have been differentiated through each eco-system organization of the platforms they have(KISDI, 2013).

In general, telecom companies are germane significantly to the government policies while making or advancing the services and products as it depends on they have to implement and consider what regulations are beneficial to consumers under equitable competition. Take South Korea's M\&A case, for example, in order to burgeon the development of its telecommunications industry, $\mathrm{KT}$ (Korea Telecom), the largest telecom operator in South Korea, asked for a government accreditation of the merge and

${ }^{*}$ Corresponding Author 
acquisition of KTF, KT's subsidiary company in 2008. The Korea Fair Trade Commission (KFTC), which monitors all of regulations and policies released by government such as promoting competition, strengthening consumers' rights and restraining concentration of economic power, granted KT's request on January, 2009 through a strictly judging process. By obtaining its approval, KT's dominant market power was proportional to be waxed. Furthermore, This M\&A brought a cardinal implication because if KFTC had not granted the permission to KT, telecommunications industry in South Korea would not have been able to advance its sector. Finally KT took the leader with respect to global telecommunication trends after this event such as releasing the first service in the world for 'broadband service LTE-A', 'Set-top box type of UHD broadcast service', and a provision of faster internet speed than optic local area network and telephone wire.

Recently, many telecom companies in the world tend to take over other firms, which can provide consumers with related ICT services. For example, SoftBank Corp., is a Japanese telecom operator, providing broadband, fixed-line telecommunications, ecommerce, the internet, and eclectic multimedia services. The SoftBank had announced to acquire $70 \%$ interest of the third largest U.S. telecommunications company, Sprint Nextel Corporation by $\$ 20.1$ billion on October 14,2012 . The deal officially was approved by the FCC on July 5, 2013, for $\$ 21.6$ billion of 78 percent shares in which $\$ 5$ billion of it is for the capital. Besides, in 2014, they have prepared for another buyout of which the name of a company they want is the 'T-Mobile'. Originally, M\&A of telecommunications industry had to be epidemic in the past time, mid of 2000's. It however, has been revived with advancing new products at the same time. Following that the established operators have a big build, the competitive landscape has transferred into bundling service including mobile(OECD, 2013; KISDI, 2013). This case applies to South Korea as well. Especially, since market saturation in 2007, the bundling battle among rivals in South Korea market has been currently keen. There were shreds of evidence in report for 'Telecommunications Market evaluation in 2014'written by KISDI. It denoted that $81.7 \%$ used to bundling service( $\mathrm{N}=3,056)$. Of the results, total samples $2,697,80.1 \%$ for using broadband, $50 \%$ for using mobile service and $44 \%$ for IPTV are presented by Figure 1 below. On the contrary surprisingly, its competition within OECD countries is less than South Korea market. According to OECD surveys in report of 'Broadband bundling in 2011 ', The rate of $77 \%$ allows users to buy stand-alone broadband service with $17 \%$ tied broadband service to a fixed-line voice service and $4 \%$ required a television package to obtain broadband access. Only two percent of the offers required subscribers to take a triple-play service to have broadband. The Figure 2 below shows the evidence as mentioned above.

Bundling can provide both benefits and drawbacks to broadband customers. Their services are generally less expensive when purchased together, and consumer surplus from one good in the bundle can help "subsidize" another less-valued element. It also allows the integration of products in a way that benefits to consumers such as by giving them unified billing, a common helpline number or the integration of voice mail message retrieval via the television set(OECD, 2011). 


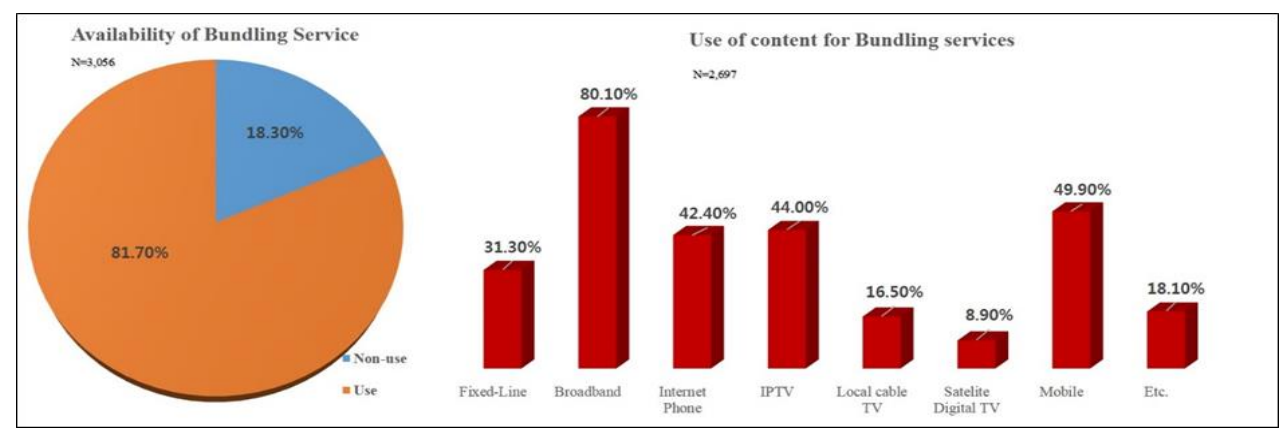

Sources: KISDI(2014)-reconstructed

Figure 1. Availability of Bundling Including all Services in South Korea

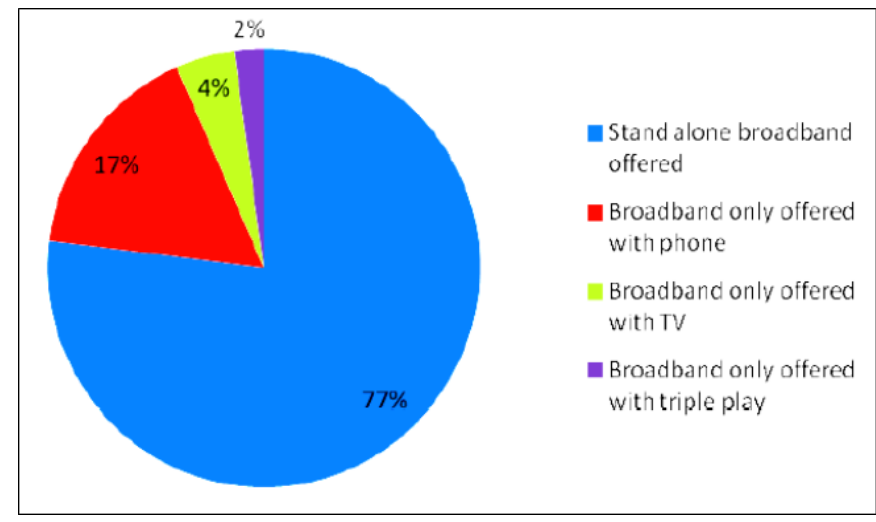

Sources: Broadband bundling, OECD(2011)

Figure 2. Availability of Stand-Alone Broadband Offers from 90 Operators

Our study is an effort to construe how bundled product creates pricing and revenues in the network externality of telecommunication service sector. What our works have characteristics is that single product and multiple products have benefits to consumers and which bundling prefers to make more contracts with subscribers, market share, and financial merits. Plus, we present an issue of bundling products and extrapolate from evidence suggesting that how they influence on the relationship between the growth of resale market and bundling products as it is becoming the major issue currently in telecommunication service market.

The organizations of our paper are as follows. The introduction gives a brief overview of this research's purpose and describes why bundled product has issues in this area. The next section espouses to build out the hypotheses whether relationships between bundling services and revenues within annually financial data of company have to be positive or not in convergence environment though previous research and business and economics theories. The methodological framework is presented in Section 3 with empirical data, which is gathered from KISDI(Korea Information Society Development Institute), that is one of notable public institute about the ICT regulations and policies in Asia. Section 4 elucidates the consequences of our hypotheses. Discussion and concluding remarks are presented in Section 5.

\section{A Theoretical Framework for Hypotheses}

Telecommunication service providers around the world have embraced bundling services as an overarching strategies to grapple with diminishing profits and have created the breakthrough in their market, since market saturation in 2007. Currently, they have 
tended forward to major strategies that they tried to obtain unrelated resources like more homogeneous or heterogeneous factors than their resources by propelling merger and acquisitions(M\&A) from other companies. A reason why they wanted to take over other firms is to broaden scale and scope of their competitive markets. It turned out that in telecommunication service market, bundling services have emerged multiple services such as typical bundles offer fixed-voice, data, and video services are commonly referred to as "multiple-play" or "triple-play" packages. The number of operators is augmenting their bundled products to include mobile voice as a fourth component of "quadruple-play" offers. As I mentioned above that fundamentally, the bundling is commonly defined as the sale of two or more separate products in one package(Stremersch and Tellis, 2002). In this section, this paper delineates the relationships among revenues and operators, bundling and market power, and taking advantage from competitive battle. In order to espouse and build up our hypotheses, we utilize some theories, which are within formal business and economics. These are: 1) network externality in resource-based view on which the properties of bundling can expound; 2) how much bundling effects in firm have their market power and 3) Finally, we consider strategic options, which come from price discrimination and lock-in to provide customer network with the product utilities.

\subsection{Network Externality in the Resource-Based View(RBV)}

The firm's resource is as the fundamental determinants of competitive advantages and performance. There are two critical assumptions in the Resource-Based View(RBV), by analyzing sources of competitive advantage(Barney, 1991; Peteraf and Barney, 2003). First, the assumption is pertinent to resource heterogeneity that the sources and capabilities of bundles differentiate across firms in the same industry or even the same strategic group. For example, telecom operators in South Korea, KT(Korea Telecom), SKT(SK Telecom), even though both KT and SKT compete in the same strategic industry, they have performed different resource bundles as well as profit structure. Since KT's principle commodities are fixed-line and broadband services with remarkable LAN(Local Area Network), while SKT has the outstanding quality of mobile communication. The second, it assumes that resource heterogeneity may persist over time because it used to implement firm's strategies, not perfectly mobile across firms(Trujjens, 2003). Each company has their own resources that are unique and individualized to their own. It is arduous to build different spectrums of resources as well as its bundle distinguishes across firms. Therefore, this difference can maintain their benefits for extended periods of time. As similar with RBV, David and Rukstad(2008) suggested that how the companies apply for their resources, that are organized by the fundamental elements of a strategy statement such as: 1) objective(=ends) that the choice of target has a profound impact on a firm; 2) scope(=domain) that a company's scope encompasses three dimensions; customer or offering, geographic location, and vertical integration. And; 3) advantage(=mean), in given that a sustainable competitive advantage is the essence of strategy, it should be no surprise that advantage is the most critical aspect of a strategic statement. Especially, in the telecommunication services market the resource can be installed-base, which was accumulated by network externality.

Network externality arises when user's benefit from using a technology increased with the number of other users employing the same technology(Katz and Shapiro, 1986). The classic examples occur in markets involving physical networks such as rail-roads or telecommunications(Scilling, 2002). Customer network in telecommunication industry is not only a valuable resources but also immobile assets, which are cumulative effects through network externality, as for some goods one person's demand also depends on the demands of other people. In particular, it may be affected by the number of other people who have purchased the goods due to the bandwagon effect that is positive network externality in which a consumer wishes to possess a good in part because others 
do(Pindyck and Rubinfeld, 2013). Generally, in order to estimate the demand of network externality, we need the price and quantity data from the historical market information.

Based on empiricism, one of features in this research builds real data in which how customer network or installed-base affects with respect to market power and firm's financial indexes. A firm's customer network is an important strategic asset that can be used to gain a competitive advantage as well as it helps a firm gain an advantage by creating an isolating mechanism (Shankar and Bayus, 2003). Montgomery and Wenerfelt(1988) illuminated that a firm's customer network can create switching costs for prospective buyers of a competing firm's product, and network externalities, as measured by the size of product's installed base, significantly increased(Brynjolfsson and Kemerer, 1996). They examined the effects of network externalities, standard, intrinsic features and a time trend on microcomputer spreadsheet software prices through a hedonic model.

Previous research has demonstrated that there were empirical supports for installedbase effects on technology adoption(Schilling, 2002; Cottrell, 1998; Shurmer, 1993; Wade, 1995) because the value of product depends on the current and past network size and with linear utilities the network benefit is proportional to the size of the network and hence the future benefit is larger for the leader than for the follower and the leader has larger incentives to decrease prices the larger the network advantage and higher discount factor(Mitchell and Skrzypacz, 2006). A large installed-base extends the range of user's network increases the value of the user's training in the particular technology, an attraction for more developers of complementary technologies, thus increasing the number of options available to the user(Choi, 1994; Katz and Shapiro, 1986). The number, quality, availability and prices of these complementary products vary favorably with the size of the network. Furthermore, the complementary products improve frequently but are to some extent durable. The value depends not only on the current size of the network but also on the installed base. As mentioned above, in telecommunication service market, customer network is to determine overarching factor as it rivets directly on firm's revenue mechanism and can afford competitive advantages. Thus, we propose:

Hypothesis 1: The installed-base with bundled product by network externality will be positively associated with corporate performance in telecom providers of oligopoly market.

Hypothesis 2: The different installed-base sizes of bundled product between single and multiple products will be associated with corporate performance in telecom providers of oligopoly market. Plus, the economic effect of multiple products will be larger than a single product.

\subsection{Bundled Products in Market Power View}

2.2.1. Single Vs. Bundled Products in Non-Competitive and Competitive Market: The products are considered as separate items when markets exist for each product and when some purchasers buy or want to buy the products separately. Telecommunication bundles clearly fit into this definition given that separate markets exist for broadband access, fixed line telephony and video. While these telecommunication services are commonly sold as a bundle there remains a significant market for individual services(2011, OECD).

As denoted earlier, due to convergence environment telecom operators have to launch their products on the market in conjunction with related or unrelated products, because they want to be puissant such as having huge market power with eclectic products. Fundamentally, market power is appurtenant to diversification. Montgomery(1985) accounted for three perspectives of corporate diversification like 1) market power view, which is more dominance than efficiency, 2) agency view in which manager are not interested in augmenting profit, they only go through with diversification to protect their 
position, and 3) resource base view that is advantageous widely against competitors, if unique resources use. In several decades, diversification has demonstrated product diversification by Hitt, Hoskisson, Kim (1997) looks into the effects of international and product diversification on company performance that the results were associated with positive correlation. Luo (2002) proved that product diversification by international joint venture in emerging markets improved the international joint venture company's results. Product diversification allowed the company to obtain a competitive advantage through both using the size of the economy and expanding the market(Lee, 2003). Kim and Lee(2014) vindicated the significant relationship between platform diversification and corporate performance in telecommunication service industry.

We may think that bundling is analogous to diversification as they are composed of two or more distinct goods together for a single price. There are some reasons why firms prefer to obtain bundling services. First, it reduces the dispersion of willingness to pay. Second, the effect can be advanced barriers to entry. Bundling makes sense when customers have heterogeneous demand and when the firm can not price the discrimination due to relative valuation(Pindyck and Rubinfeld, 2013).

Rey and Tirole (2006) found that bundling can deter entry in adjacent markets when bundled goods are not compliments, at least for a substantial number of users. Bundling may allow a dominant firm to maintain its strong position in the bottleneck market. Nalebuff (2004) focused on oligopolistic firms, which most closely resemble telecommunication market structure in OECD countries. His work emphasizes that bundling allows companies with market power in two goods to bundle them together, making it harder for a rival with only one of the goods to enter the market. Importantly, bundling product allows an incumbent to defend credibly both products without having to price low in each.

This research focuses on how the relationships between single product and bundled product have ramifications with respect to market power empirically in a noncompetitive and competitive market in telecommunication service market. Nowadays, telecom providers have developed many kinds of bundling that are pure bundling and mixed bundling. According to that mentioned above, bundling in telecom service is beneficial from price competition, performance, and market dominance. In the previous research, a number of products per firm depends on concentration, and product substitutability under high competition of innovation in IT industry(Vives, 2008). These, however depend on, to be specific, the level of products in bundling. Not surprisingly, the key role of bundling is to extend the broadband access to those who value it less than the lowest stand-alone price in the competitive market while fixed-line and mobile market in non-competitive market have low leverage because these are already saturated in telecom industry. In other words, their ability to compete is over in its market as people tend to use prodigious and eclectic technologies. Therefore, we propose:

Hypothesis 3: In the non-competitive market, bundled product's net growth will be associated with a total net growth of bundling.

Hypothesis 4: In the competitive market, bundled product's net growth will be associated with a total net growth of bundling.

\subsubsection{Resale Business and Bundled Product in the Telecommunication Services:}

Telecommunication industry in most of the countries had been directly operated by government because of its nature of industry(e.g. initial investment, entry barriers) until the early the 1980s except for US market but this paradigm was transferred into oligopoly competitive market due to liberalization and openness of overall industry since the middle of 1980s. A resale of telecommunication service market has been emerged by following that to burgeon its industry government contrived one of deregulation strategies to pursue the regulations and policies. Basically, resale is the ability of a firm to purchase a service 
on a wholesale basis, for the purpose of reselling that same service, either alone or in combination with other services or features, to end users in direct competition with the original service provider (FCC, 1996 and Larson, 1996). Take Korea market, for example in Korea, it has been dramatically changed by technologies. When there were some demands for telecom services, technologies always gratified for them. Besides, the rapid development had enlarged to an individual service area and led to competition between businessmen. As the environment changes of telecommunication industry established companies invested enormous sunk cost that focused on building long term business equipment. They, however wanted to reconcile with short term and long term with creating revenues and low cost for entry. In such a process, one of the alternatives was a resale market in the telecommunication industry. In order to assess that relationship mentioned above, we need to construe the resale market in telecommunication line equipment or communication services of different service providers in retail type.

A resale business in 1981, U.S.A had begun in earnest from Federal Communications Commission(FCC) permitted to AT\&T, which is the largest institutional telecom providers in U.S., with giving publication right of AT\&T's personal circuit to MVNO(Mobile Virtual Network Operators) with respect to small-capacity leased line by dividing high-capacity leased line of AT\&T. A resale is conducive to MVNO because it does not need to install network and no initial investment cost, so cheap communication charges can be the biggest weapon in this industry.

A resale issue has been significant and contentious in bundling market. Kim(1999) emphasized with respect to resale market of telecommunications in which there is strength and weakness. He espoused that resale market had mainly three characteristics: 1) low cost structure that can entry market easily; 2) efficient operation management with indirect cost and labor cost compared to estimated companies; 3) no restrictions of particular LAN(=network) and technologies. While it has some weakness such as lack of information on business partners and amount of marketing expenses. Does resale market have tremendous importance in telecommunication service market? Does it transfer into market power directly? These are cardinal research question in this work. In general, by admitting resale from the government, many MVNOs have emerged, as it made entry barriers lower than before. As a result, we propose:

Hypothesis 5: Bundling's net growth will be associated with resale's net growth in the level of product on the competitive market

\section{Methods}

Industry Overview. The telecommunications industry in South Korea has been prodigiously advanced in the short term. There are some evidences which are major indexes such as the world's number 1 internet population(ITU, 2010), the first country for internet speed(Forbes, 2014), and the world's second largest mobile phone market(21\%). A one of cardinal reasons why South Korea's telecom industry rapidly has developed was due to cooperation from government and stable organizations to activate an improvement. South Korea has oligopoly market in their industry where three major firms are taken by KT(Korea Telecom), SKT(SK Telecom) and LG U(LG U plus). Korea government has attenuated the regulations with respect to bundling services to mitigate its competitive market since July 2007. According to KISDI report(2014), bundling subscribers of telecom operators, cable TV and SO(System Operator) are steadily augmented as 15.54 million after deregulation of telecom market from government, Korea Communications Commission(KCC). Based on 18.21 million of households by the end of 2013, 85.3\% of households in South Korea have been using bundling services, which are nine times compared in 2007. The first bundling product was released in February 2008 including Public Switched Telephone Network(PSTN), which is same to fixed line. By being M\&A with KT and KTF, which was as the subsidiary company of KT, the telecom operators 
integrated with wired and wireless are in a high competition of bundling with mobile services. Meanwhile, bundling product of three major telecom firms in South Korea have focused on high-speed internet and subscribers have increased rapidly as well(from $66.3 \%$ in 2011 to $70.6 \%$ in 2012 , nearly 9.7 million subscribers).

Bundled Product Issues. In such a process mentioned above, there have been three issues in bundling market. First, why do they obsess with respect to bundling product? Does it create to be profitable to service providers? The effects associated with a customer network are not only a function of network size but also network strength and a firm's network size are equivalent to its installed base, while network strength can be viewed as marginal impact of unit increase in network size on demand(Shankar and Bayus, 2003). Typically, the cost of bundling product is cheaper $10 \%$ than the sum of a single product(KISDI, 2014). That means small possibility to switch single product, even though it would be increased by $10 \%$ whereas separately, single product $10 \%$ increase in rates is likely to result in greater demand substitutability so there will be the phenomenon from single product to bundling product. In general, demand substitutability tends to be higher when consumer with particular good overlaps for a consumer with other goods. The issue is that how net increase of single product affects on bundling net growth in the noncompetitive and competitive market. Final issues can be a resale business in bundling products because telecom operator that has market dominance for some part of telecommunication services, tends to defend reduction phenomenon of customers of its subsidiary company.

Modeling and Data. Typically, the market power of bundling can be assessed by the relationship between a single product and bundling products(=multiple products). In other words, DPS(Double Play Services), TPS(Triple Play Services) and QPS(Quadruple Play Services) are excluded from analysis in bundling products because it is a single product itself in a state in which a subscriber is based on the aggregate line. To examine the contract and the number of subscribers they are an error in the set of configuration itself such as problems of a total number of subscribers that do not match.

Table 1. Structure of the Hypotheses in this Research

\begin{tabular}{|c|c|c|}
\hline & Independent variable & Dependent variable \\
\hline H1 & $\begin{array}{l}\text { - Installed base(=Customer network) } \\
\text { - total net growth for bundling product }\end{array}$ & \multirow{2}{*}{$\begin{array}{l}\text { - Financial data of telecommunication } \\
\text { service providers } \\
\text { - Total sales(total operating revenue) } \\
\text { - ROE(Return on equity) } \\
\text { - Net profit }\end{array}$} \\
\hline H2 & $\begin{array}{l}\text { - Net growth of single product } \\
\text { - Net growth of multiple products } \\
\text { (=bundling products) }\end{array}$ & \\
\hline H3 & $\begin{array}{l}\text { - Market power of bundled product } \\
\text { in non-competitive market } \\
\text { - PSTN and mobile services } \\
\end{array}$ & - Total net growth for bundling product \\
\hline H4 & $\begin{array}{l}\text { - Market power of bundled product } \\
\text { in competitive market } \\
\text { - broadband service } \\
\end{array}$ & - Total net growth for bundling product \\
\hline H5 & $\begin{array}{l}\text { - Market power of mobile } \\
\text { - mobile to broadband services }\end{array}$ & - Resale net growth \\
\hline
\end{tabular}

Table 1 shows that we measure each hypothesis. There are five hypothetical assumptions to espouse this work: 1) to assess the hypothesis 1 , we defined installed base 
and financial data are as independent and dependent variable respectively. The installed base is anchored to KT's total subscribers of each bundling products from collecting each bundling product from second quarter of 2007 to 2013 monthly like PSTN(Public Switched Telephone Network), broadband, and mobile services. A reason why setting a year from the second quarter of 2007 gleaned is that government had promulgated a permission of telecommunication service regulations to sell bundling product to telecom operators at that times. The total net growth can be evaluated by that its net growth of single product is divided by an aggregate net growth of the single individual product. The financial data gathered from KT such as total sales, total assets, EBITDA(Earnings Before Interest, Tax, Depreciation and Amortization), and net profit since KT has possessed market share of total bundling products nearly 54\% in South Korea up to current time(KISDI, 2013); 2) Hypothesis 2 denotes that how much single and multiple products have an influence on economic performance of firm. Furthermore, we figure out for the difference between single and multiple products. In other words, by running ANOVA analysis of two groups, product type has importance regarding the size of installed base with being transferred data as log value and normal distribution. We extrapolate that they really have a significant relationship. To do this measurement, we utilize as a single product like the number of subscriber of KT's broadband service, because it has huge proportion of bundled product as well as the most competitive product in telecommunications service market and as multiple products which are made up of bundled product including broadband service consistently being compared with single product. As noted above, bundling products are aggregate lines from single product. We presume that setting different installed base size for relationship between single product and multiple products has an effect on corporate performance, also we set that the background of hypothesis 1 and 2 is within oligopoly market as telecommunications service market in South Korea, which is operated by three major companies; 3) In general, PSTN and mobile service can be classified as products in non-competitive market of telecommunications service industry because not only most people use these services in their market of households, but these markets have saturation(KISDI, 2014). Hypothesis 3 notes that market power of single product such as PSTN and mobile services in the non-competitive market has not association with the market power of bundled products. By analyzing these variables, policy makers can distinguish how strategy of product differentiation has for obtaining future strategic options in companies; 4) According to 2014 KISDI survey, with respect to bundled products, most respondents who do not currently subscribe to bundling will use them, which are based on broadband service. It is useful resource to get dominance of market power to telecom operators(OECD, 2011); 5) Resale issue in telecommunications service market of South Korea has emerged significantly because resale of high speed internet in SKT is defending reduction of SKT's mobile. In order to assess hypothesis 5, there are two steps to analyze, In South Korea, SKT has possessed most of market share for mobile sector's bundled product so first step is to figure out to market power of SKT mobile such as dominance and then second step is to compare with net growth of SKT resale.

To measure empirically these hypotheses mentioned above, trustworthy data gathered from KISDI to which three major telecom operators in South Korea annually submit bundled product data. About hypothesis 3 and 4, we propose that market power of the single product in a non-competitive and competitive market has strong the influence on transference power of bundling products. We recognized that bundling product market, which subsumes KT's PSTN and SKT's mobile sector and significantly competitive advantage services like KT's broadband sector was configured as a range of analysis. Through the model of Granger's causality, we examine that whether a single product market can affect on bundling product market or bundling product market influences to other single product markets. An equation (1) represents larger explanatory power than an equation (2) but it does not mean that $\mathrm{X}$ does not cause $\mathrm{Y}$. The difference between them 
depends on the existence of $X_{t-k}$. The significance of regression (1) and (2) tests F-value to use SSR(Sum of Squared Regression).

$$
\begin{aligned}
& Y_{t}=\alpha+\sum_{k=1}^{m} \beta_{k} Y_{t-k}+\sum_{k=1}^{m} \gamma_{k} X_{t-k}+e_{t} \\
& Y_{t}=\alpha+\sum_{k=1}^{m} \beta_{k} Y_{t-k}+e_{t}
\end{aligned}
$$

It is utilized in many time series analysis as a model to determine if one of the economic variables has precedence and explanatory power of the other variables. To do this, we use a share of the subscriber, which is as an index to judge a market dominance. In addition to that Granger causality test utilizes a monthly time series data from June 2007 to December 2013 because it is overarching reason to secure sufficient time series data. Therefore, we used net growth of subscriber as analysis model to consider competitive situation in the present time, not reflecting past trends because there are existent Random Walk and White noise effect to control when time series analysis runs. Net growth of subscriber represents market share based on the increase compared to previous month, stability of time series data as well as dynamic impact like service subscription(+) or cancellation(-). In order to analyze these data, we used MINITAB, which is statistical software package program.

\section{Results}

Table 2 contains the means, standard deviation, and correlations of variables with respect to hypothesis 1 and 2 . As shown, there is a high degree correlation among all of independent variables, which can cause the relationships between independent variables and dependent variables to be understated in the regression model. In particular, the installed base was highly associated with corporate performance, indicating support for Hypothesis 1. By the way, we ran regression and ANOVA analysis for Hypothesis 2. Even though P-value for net growth of single product was significant, a constant value was negative to all dependent variables.

Table 2. Means, Standard Deviations, Pearson Correlations about H1 and H2

\begin{tabular}{llllll}
\hline & \multirow{2}{*}{ Means } & S.d & \multicolumn{3}{c}{ Pearson Correlation } \\
& & & \multicolumn{2}{c}{ P-value } \\
\cline { 4 - 5 } & & Total Sales & EBITDA & Total Assets \\
\hline \multirow{2}{*}{ Installed based } & 8.847 & 1.464 & 0.797 & 0.302 & 0.798 \\
& & & $0.000^{* * * *}$ & $0.100^{*}$ & $0.000^{* * * *}$ \\
Single Product & 8.901 & 0.081 & 0.903 & 0.452 & 0.969 \\
Multiple & & & $0.000^{* * * *}$ & $0.010^{* * *}$ & $0.000^{* * * *}$ \\
Products & 7.875 & 0.243 & 0.763 & 0.283 & 0.766 \\
\hline
\end{tabular}

$* * \mathrm{p}<.05, * * * \mathrm{p}<.01, * * * * \mathrm{p}<.001$

Table 3 shows that the difference in which product type has importance with the size of installed base was strongly significant at 0.000 level of p-value(see the Appendix). It denotes that if a subscriber of a single product, increases by 1, corporate performance would be reduced negatively. In regression analysis with Hypothesis 1 and 2, all data transferred into $\log$ value because the measured value of the dependent variable $\mathrm{Y}$ 
corresponding to the independent variable $\mathrm{X}$ should be within standard distribution. From the Table 4, we analyzed with MINITAB regression. It is clear that all independent variables were significant at 0.01 and 0.001 level and construed if subscriber increases by 1 person about the installed base, then total sales, total assets, and EBITDA were predicted to change by $\$ 0.16,0.14$, and 0.06 respectively. As a result, Hypothesis 1 and 2 supported as proposed.

Table 3. ANOVA Analysis: Size of Installed Base Vs. Type of Product about $\mathrm{H} 2$

\begin{tabular}{ccccccr}
\hline Source & DF & SS & MS & F & P \\
\hline $\begin{array}{c}\text { Type of } \\
\text { Product }\end{array}$ & 1 & 15.504 & 15.504 & 18.01 & $0.000^{* * * *}$ \\
$\mathrm{~S}=0.9279 \mathrm{R}-\mathrm{Sq}=24.33 \%$ & $\mathrm{R}-\mathrm{Sq}(\mathrm{adj})=22.98 \%$ & & & & \\
\hline$* * * * \mathrm{p}<.001$ & & & & & & \\
\hline
\end{tabular}

Table 4. Results of Regression Analysis about H1 and H2

\begin{tabular}{|c|c|c|c|c|c|c|c|c|c|}
\hline \multirow[b]{2}{*}{ Variable } & \multicolumn{3}{|c|}{ Total sales } & \multicolumn{3}{|c|}{ EBITDA } & \multicolumn{3}{|c|}{ Total assets } \\
\hline & Coef & R-sq & P-val & Coef & R-sq & P-val & Coef & R-sq & P-val \\
\hline $\begin{array}{c}\text { Installed } \\
\text { Base }\end{array}$ & 0.16 & 63.6 & $0.000 * * * *$ & 0.06 & 9.1 & $0.1 *$ & 0.14 & 63.7 & $0.000 * * * *$ \\
\hline $\begin{array}{c}\text { Single } \\
\text { Product }\end{array}$ & 3.19 & 81.6 & $0.000 * * * *$ & 1.63 & 20.4 & $0.01 * * *$ & 3.01 & 93.9 & $0.000 * * * *$ \\
\hline $\begin{array}{l}\text { Multiple } \\
\text { Products }\end{array}$ & 0.17 & 58.3 & $0.000 * * * *$ & 0.06 & 8.0 & $0.1 *$ & 0.15 & 58.7 & $0.000 * * * *$ \\
\hline
\end{tabular}

$* \mathrm{p}<0.1, * * \mathrm{p}<.05, * * * \mathrm{p}<.01, * * * * \mathrm{p}<.001$

Table 5 shows results for Granger causality test with respect to Hypothesis 3 and 4 . KT's net growth of single product like PSTN was not significant to net growth of bundled product which includes PSTN as well as SKT's net growth of single product was not relative to net growth of bundled product which subsumes mobile. As a result, in the noncompetitive market, a single product does not affect on the market dominance of bundled product. However, Hypothesis 4 was supportive to bundled product as p-value was significant at the 0.1 level. It means that in a competitive market, like broadband service, single product influences on the market dominance of bundled product. Therefore, Hypothesis was supported as suggested. 
Table 5. Results for Granger Causality Test: H3, H4

\begin{tabular}{|c|c|c|c|c|}
\hline & & Lag & F-Statistic & Probability \\
\hline \multirow{5}{*}{ Hypothesis 3} & Net growth of Single Product(PSTN) $\nRightarrow$ & 1 & 1.21995 & 0.27295 \\
\hline & Net growth of Bundled Product(PSTN) & 2 & 0.77072 & 0.46651 \\
\hline & & & & \\
\hline & Net growth of Single Product(Mobile) $\nRightarrow$ & 1 & 0.06097 & 0.80566 \\
\hline & Net growth of Bundled Product(Mobile) & 2 & 0.21387 & 0.80797 \\
\hline \multirow{2}{*}{ Hypothesis 4} & Net growth of Single Product(Broadband) $\Rightarrow$ & 1 & 2.93650 & $0.090788 *$ \\
\hline & Net growth of Bundled Product(Broadband) & 2 & 1.83255 & 0.16749 \\
\hline
\end{tabular}

$* \mathrm{p}<.10$

From the Table 6, it is clear that there are no relationships between the resale issue. In order to evaluate Hypothesis 5 correctly, we defined two sectors: 1) relationship between SKT's mobile market dominance and resale net growth for broadband market dominance; 2) SKT's net growth of single broadband service and resale net growth of bundled product which includes broadband service because we assumed that SKT had the largest market dominance with mobile sector, so their market dominance may affect resale business of bundle product that includes broadband services.

Table 6. Result for Granger Causality Test: H5

\begin{tabular}{cccc}
\hline Hypothesis 5 & Lag & F-Statistic & Probability \\
\hline Net growth of Single Product(Mobile) $\nRightarrow$ & 1 & 0.00889 & 0.92533 \\
Resale net growth of Single Product(Broadband) & 2 & 0.00268 & 0.99733 \\
\cline { 2 - 4 } Net growth of Single Product(Broadband) $\nRightarrow$ & 1 & 0.11919 & 0.73092 \\
Resale net growth of Bundled Product(Broadband) & 2 & 0.10991 & 0.89607 \\
\hline
\end{tabular}

In sum, the results of this work indicate most models have the great explanatory power of bundling markets except the products in the non-competitive market and resale issue. Especially, with respect to Hypothesis 2, we eliminated the heteroskedasticity to obtain the accurate value in an environment of a standard distribution. In addition, overall fits of the models were significant, and setting data organization had significance such as being stable by ADF test for time series data, although two assumptions like Hypothesis 3 and 5 were not significant.

\section{Discussion}

\subsection{Contribution}

Many former researches have substantiated that in several industries for which network effects are important, a typical situation is one in which there are multiple competing product technologies that are incompatible (Voortman, 1993). Some of RBV's seminal papers mention in passing that customer bases can be valuable resources (e.g., Barney, 
1986: 1235; Dierickx and Cool, 1989: 1508). Consistent with this view, in telecommunications service market, network externality affects subscribers of single and multiple product as well as firm's financial data and market dominance of bundled products that are particularly in a competitive market. This study yields two significant contributions to the research field and managerial of bundling market. First, in an academic perspective, we found an evidence vindicated with trustworthy data that installed base, difference between single and bundled products that are same with customer network in telecommunication service market had strong relationship with corporate performance. The bundling research field is wild area because it is abstruse without real data to demonstrate even though it can be demonstrated by some prediction models such as the Delphi technique, demand prediction analysis. According to $\operatorname{OECD}(2011)$ report for bundling research, it may rely on a survey because of that difficulties. Furthermore, we empirically advanced a theory of network externality in information economics, the resourced-based view and the market power view as hypothesized.

Second, in managerial perspective, we denoted practical implications that telecom companies, which include market dominance in their product groups may utilize competitive advantages because operators can use eclectic strategic options to be more profitable by having entry barriers at the same time being avoidable for cannibalization. Therefore, the marketing and entry of products into a market is among the most important decisions that a firm has to cope with (Tran et. al., 2012). When they release a new product, in general, firms not only tend to block other operators to entry either noncompetitive or competitive market to maintain own market share but also, their strategic options are bounded the environment. In other words, structure shapes strategies (Kim and Mauborgne, 2009). This contribution has tremendous importance as well as when they take over several service providers. Additionally, this research showed the size of installed base, product in the competitive market influenced the performance and market dominance of bundling. For example, firms can make the product differentiation of bundling. In other words, it is a strategy to avoid price competition by monopolizing the attention of buyers in addition to its product characteristics and competitive products clearly identified, because product differentiation provides consumers with a variety of different products within a particular industry, rather than a homogeneous product that characterizes purely competitive markets(Randall, 2009).

\subsection{Limitations and Future Research}

There are methodologically two limitations in this work. First of all, methodologically we need to consider moderating variables as the second independent variable because they can deal with strength level of the relationship when independent variables influence on the dependent variables. Take this research, for example, by setting an environment for convergence, we may know that how much single and bundled products have strength level to a financial statement. Second, due to lack of sample size in time series data for resale issues, Hypothesis 5 was not statistically significant because the government had accepted SKT's request with respect to resale business in 2010. Therefore, subsequently, it is necessary to analyze the dominant transition of a market while collecting relevant data.

Future research could focus on, in particular, switching cost in bundling market. This issue is cardinal research field to figure out for a relationship between consumers and producers. The reason is that consumer-producer surplus approach can be determinants for prediction of demands, an efficiency of distribution to them. Furthermore, there is clearly testable that how much producers can give consumer benefit to existent subscribers, firms not only can induce more customer networks as well as by reducing switching cost but also utilize lock-in strategy. Another important direction for this research is pertinent to relationship between M\&A and bundling market as nowadays, in 
order to efficiently reinforce the lack of resources in telecom operators, they prefer to take over several companies that want to obtain the resources they are interested in.

\section{References}

[1] J. Wiiliams and Y. L. Janet, "Commodity bundling and the burden of monopoly", The Quarterly Journal of Economics, vol. 90, no. 3, (1976), pp. 475-498.

[2] B. Jay, "Strategic factor markets: expectations, luck, and business strategy", Management Science, vol. 42, (1986), pp. 1231-1241.

[3] J. Barney, "Firm Resources and Sustained Competitive Advantage", Journal of Management, vol. 17, no. 1, (1991), pp. 99-120.

[4] B. Erik and F. Kemerer Chris, "Network Externalities in Microcomputer Software: An Econometric Analysis of the Spreadsheet Market", Management Science, vol. 42, no. 12, (1996) December, pp. 16271647.

[5] T. Cottrell, "Software variety and hardware value: A case study of complementary network externalities in the microcomputer software industry", Journal of Engineering and Technology Management, vol. 15, (1998), pp. 309-339.

[6] D. J. Collis and M. G. Rukstad, "Can You Say What Your Strategy Is?”, Harvard Business Review (2008) April.

[7] I. Dierickx and K. Cool, "Asset stock accumulation and sustainability of competitive advantage", Management Science, vol. 35, (1989), pp. 1504-1514.

[8] M. A. Hitt, R. E. Hoskisson and H. C. Kim, "International Diversification: Effects on Innovation and Firm Performance in Product Diversified Firms", Academy of Management Journal, vol. 40, no. 4, (1997), pp. 767-798.

[9] M. Katz and C. Shapiro, "Technology adoption in the presence of network externalities", Journal of Political Economy, vol. 94, (1986), pp. 822-841.

[10] K. B. Kim and S. M. Lee, "Does platform diversificacomtion directly influence on performance?", International Journal of Business Research, vol. 14, no. 1, (2014), pp. 45-56.

[11] J. K. Kim, "Environmental changes and Business analysis in resale market", Information Telecommunication policy, vol. 10, no. 11, (1999).

[12] W. C. Kim and R Mauborgne, "How strategy shapes structure", Harvard Business Review Septemner (2009).

[13] KISDI - Korea Information Society Development Institute, Telecommunications Market evaluation (2013).

[14] KISDI - Korea Information Society Development Institute, Telecommunications Market evaluation (2014).

[15] J. H. Lee, "International diversification, product diversification, and organizational learning impact on the value of the company”, Korean Academic Society of Business Administration, vol. 32, no. 5, (2003), pp. 1291-1315.

[16] Y. Luo, "Product Diversification in International Joint Ventures: Performance Implications in an emerging market", Strategic Management Journal, vol. 23, no. 1, (2002), pp. 1-20.

[17] C. A. Montgomery, "Product-Market Diversification and Market Power", Academy of Management Journal, vol. 28, (1985), pp. 789-798.

[18] F. M. Mitchell and A. Skrzypacz, "Network Externalities and Long-Run Market Shares, Economic Theory", vol. 29, no. 3, (2006) November, pp. 621-648.

[19] OECD, "Broadband Bundling: Trends and Policy Implications", OECD Digital Economy OECD Publishing, vol. 175, (2011).

[20] OECD, "OECD Communications Outlook (2013).

[21] S. A. Melissa, "Technology Success and Failure in Winner-Take-All Markets: The Impact of Learning Orientation, Timing, and Network Externalities", Academy of Management Journal, vol. 45, no. 2, (2002), pp. 387-398.

[22] V. Shankar and B. L.Bayus, "Network Effects and Competition: An Empirical Analysis of the Home Video Game Industry", Strategic Management Journal, vol. 24, (2003), pp. 375-384.

[23] S. Stremersch and G. J.Tellis, "Strategic Bundling of Products and Prices: A New Synthesis for Marketing", The Journal of Marketing, vol. 66, no. 1, (2002) January, pp. 55-72.

[24] D. V. Tran, D. S. Sibley and S. Wilkie, "Second mover advantage and entry timing", The Journal of Industrial Economics, vol. LX, no. 3, (2012), pp. 517-535.

[25] M. Peteraf and J. Barney, "Unraveling The Resource-Based Tangle", Managerial and Decision Economics, vol. 24, (2003), pp. 309-323.

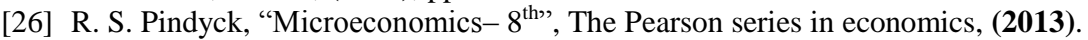

[27] R. G. Holcombe, "Product differentiation and economic progress", The quarterly Journal of Austrian Economics, vol. 12, no. 1, (2009), pp. 17-35.

[28] O. Truijens, "A Critical Review of the Resource-based View of the Firm", University of Amsterdam, Netherlands. Sprouts: Working Papers on Information Systems, vol. 3, no. 6, (2003). 
[29] J. Wade, "Dynamics of organizational communities and technological bandwagons: An empirical investigation of community evolution in the microprocessor market", Strategic Management Journal 16 special issue, (1995), pp. 111-134.

[30] X. Vives, "Innovation and competitive pressure", The Journal of Industrial Economics, vol. LVI, no. 3, (2008), pp. 419-469.

[31] J. Voortman, “Curbing aftermarket monopolization”, Antitrust Bulletin 39 Summer, (1993), pp. 221-291.

\section{Appendix}

\section{a) Hypothesis 1}
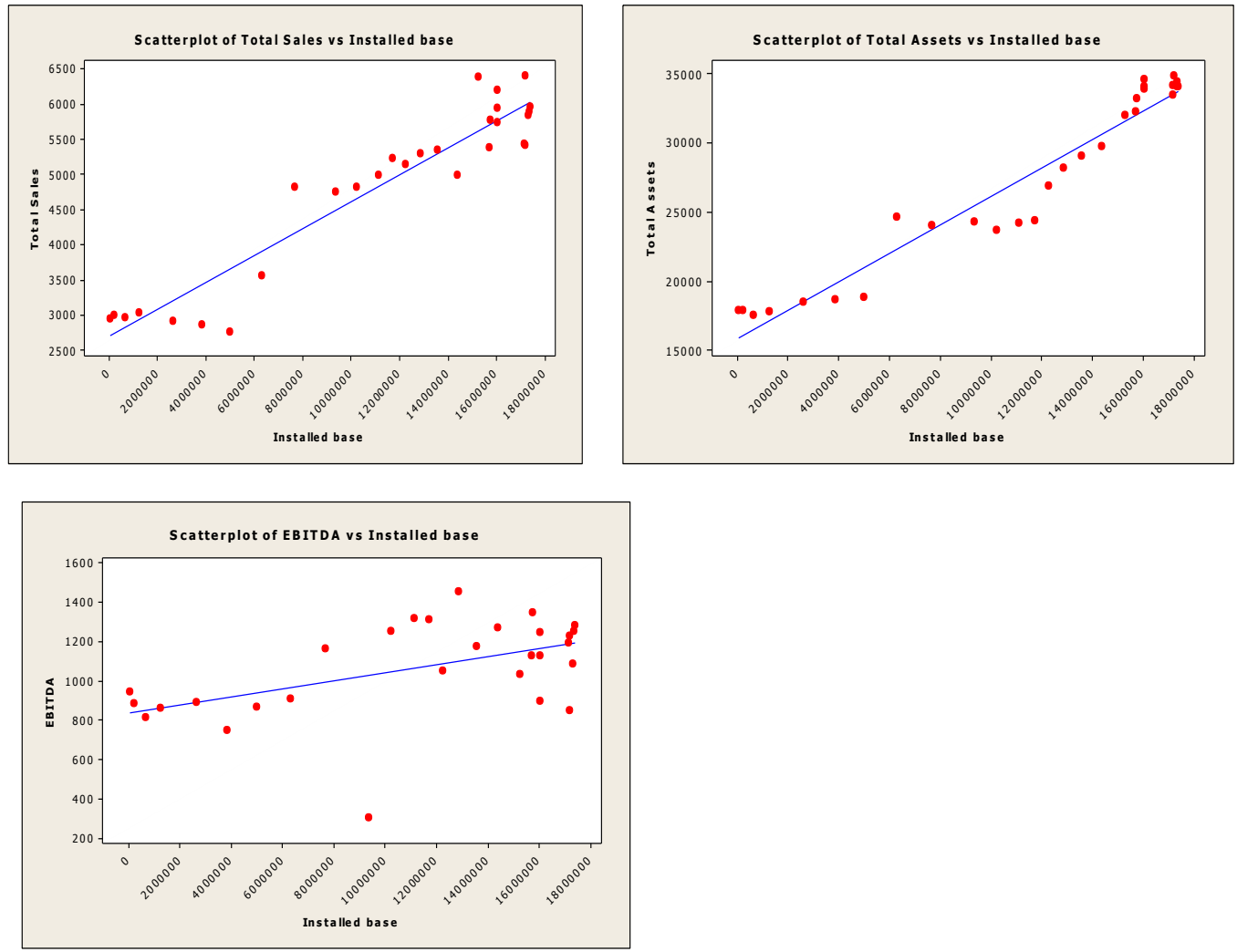

\section{b) Hypothesis 2}

(1) Regression Analysis: Total Sales versus Single product

The regression equation is Total Sales $=-20.1+3.20$ Single product

Predictor

Constant

Coef SE Coef $\mathrm{T} \quad \mathrm{P}$

Single product

$$
\begin{array}{llll}
-20.061 & 2.606 & -7.70 & 0.000
\end{array}
$$

$$
\begin{array}{llll}
3.1997 & 0.2925 & 10.94 & 0.000
\end{array}
$$

$$
\mathrm{S}=0.125728 \quad \mathrm{R}-\mathrm{Sq}=81.6 \% \quad \mathrm{R}-\mathrm{Sq}(\mathrm{adj})=80.9 \%
$$

(2) Regression Analysis: EBITDA versus Single product

The regression equation is EBITDA $=-7.59+1.63$ Single product

Predictor Coef SE Coef T P

$\begin{array}{lllll}\text { Constant } & -7.594 & 5.522 & -1.38 & 0.180\end{array}$

Single product $\begin{array}{llll}1.6310 & 0.6199 & 2.63 & 0.014\end{array}$ 


$$
\mathrm{S}=0.266414 \quad \mathrm{R}-\mathrm{Sq}=20.4 \% \quad \mathrm{R}-\mathrm{Sq}(\operatorname{adj})=17.5 \%
$$

(3) Regression Analysis: Total Assets versus Single product

The regression equation is Total Assets $=-16.6+3.01$ Single product

$$
\begin{array}{lllll}
\text { Predictor } & \text { Coef } & \text { SE Coef } & \multicolumn{2}{c}{\text { P }} \\
\text { Constant } & -16.641 & 1.317 & -12.64 & 0.000 \\
\text { Single product } & 3.0112 & 0.1478 & 20.37 & 0.000 \\
& & & & \\
\text { S }=0.0635357 & \text { R-Sq }=93.9 \% & \text { R-Sq(adj) }=93.7 \%
\end{array}
$$

\begin{tabular}{|c|c|c|c|c|c|c|c|}
\hline \multicolumn{4}{|c|}{ KT PSTN Net growth of Single Product } & \multicolumn{4}{|c|}{ KT Net growth of Bundled Product } \\
\hline \multicolumn{2}{|c|}{ Lag Length: 0} & t-Statistic & Prob.* & \multicolumn{2}{|c|}{ Lag Length: 0} & t-Statistic & Prob.* \\
\hline \multicolumn{2}{|c|}{$\begin{array}{l}\text { Augmented Dickey- } \\
\text { Fuller test statistic }\end{array}$} & -9.769613 & 0.0001 & \multicolumn{2}{|c|}{$\begin{array}{l}\text { Augmented Dickey- } \\
\text { Fuller test statistic }\end{array}$} & -8.065696 & 0.0001 \\
\hline $\begin{array}{r}\text { Test } \\
\text { critical values: }\end{array}$ & $\begin{array}{r}1 \% \text { level } \\
5 \% \text { level } \\
10 \% \text { level }\end{array}$ & $\begin{array}{r}-3.516 \\
-2.8991 \\
-2.5865\end{array}$ & & $\begin{array}{r}\text { Test } \\
\text { critical values: }\end{array}$ & $\begin{array}{c}1 \% \text { level } \\
5 \% \text { level } \\
10 \% \text { level }\end{array}$ & $\begin{array}{l}-3.5164 \\
-2.8991 \\
-2.5865\end{array}$ & \\
\hline \multicolumn{4}{|c|}{ *MacKinnon(1996) one-sides p-values. } & \multicolumn{4}{|c|}{ *MacKinnon(1996) one-sides p-values. } \\
\hline
\end{tabular}

\begin{tabular}{|c|c|c|c|c|c|c|c|}
\hline \multicolumn{4}{|c|}{ SKT Mobile Net Growth of Single Product } & \multicolumn{4}{|c|}{ SKT Mobile Net Growth of Bundled Product } \\
\hline \multicolumn{2}{|c|}{ Lag Length: 0} & $\mathrm{t}$-Statistic & Prob.* & \multicolumn{2}{|c|}{ Lag Length: 0} & $\mathrm{t}$-Statistic & Prob.* \\
\hline \multicolumn{2}{|c|}{$\begin{array}{l}\text { Augmented Dickey- } \\
\text { Fuller test statistic }\end{array}$} & -12.14180 & 0.0001 & \multicolumn{2}{|c|}{$\begin{array}{l}\text { Augmented Dickey- } \\
\text { Fuller test statistic }\end{array}$} & -9.480045 & 0.0001 \\
\hline $\begin{array}{r}\text { Test } \\
\text { critical values: }\end{array}$ & $\begin{array}{l}1 \% \text { level } \\
5 \% \text { level } \\
10 \% \text { level }\end{array}$ & $\begin{array}{l}-3.5164 \\
-2.8991 \\
-2.5865\end{array}$ & & $\begin{array}{r}\text { Test } \\
\text { critical values: }\end{array}$ & $\begin{array}{r}1 \% \text { level } \\
5 \% \text { level } \\
10 \% \text { level }\end{array}$ & $\begin{array}{l}-3.5164 \\
-2.8991 \\
-2.5865\end{array}$ & \\
\hline \multicolumn{4}{|c|}{ *MacKinnon(1996) one-sides p-values. } & \multicolumn{4}{|c|}{ *MacKinnon(1996) one-sides p-values. } \\
\hline
\end{tabular}

\section{c) Hypothesis 3}

[ Net growth rate(ADF Test): KT PSTN Single Vs. Bundled Product ]

\begin{tabular}{|c|c|c|c|c|c|c|c|}
\hline \multicolumn{4}{|c|}{ KT Broadband Net Growth of Single Product } & \multicolumn{4}{|c|}{ KT Broadband Net Growth of Bundled Product } \\
\hline \multicolumn{2}{|c|}{ Lag Length: 0} & t-Statistic & Prob.* & \multicolumn{2}{|c|}{ Lag Length: 0} & $\mathrm{t}$-Statistic & Prob.* \\
\hline \multicolumn{2}{|c|}{$\begin{array}{l}\text { Augmented Dickey- } \\
\text { Fuller test statistic }\end{array}$} & -8.895082 & 0.0001 & \multicolumn{2}{|c|}{$\begin{array}{l}\text { Augmented Dickey- } \\
\text { Fuller test statistic }\end{array}$} & -9.479548 & 0.0001 \\
\hline Test critical values: & $\begin{array}{r}1 \% \text { level } \\
5 \% \text { level } \\
10 \% \text { level }\end{array}$ & $\begin{array}{l}-3.5164 \\
-2.8991 \\
-2.5865\end{array}$ & & Test critical values: & $\begin{array}{r}1 \% \text { level } \\
5 \% \text { level } \\
10 \% \text { level }\end{array}$ & $\begin{array}{l}-3.5164 \\
-2.8991 \\
-2.5865\end{array}$ & \\
\hline \multicolumn{4}{|c|}{ *MacKinnon(1996) one-sides p-values. } & \multicolumn{4}{|c|}{ *MacKinnon(1996) one-sides p-values. } \\
\hline
\end{tabular}

[ Net growth rate(ADF Test): SKT Mobile Single and Bundled Product ]

\section{d) Hypothesis 4}

[ Net growth rate(ADF Test): KT Broadband Single Product Vs. Bundled Product ] 


\section{Authors}

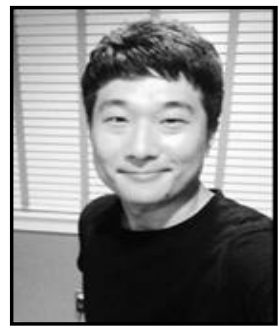

Kyungbok Kim, Ph.D. student at Department of Economics AuburnUniversity, AL, U.S.A.

- MA in Economics at University at Buffalo, SUNY, NY, U.S.A.

- MS in Business(Strategy) at Hanyang University, Korea

- BA in Business at Korea University, Korea

- Worked as Researcher in KISDI(Korea Information Society

Development Institute)

- Worked as Senior Consultant in KMAC(Korea Management Association Consulting, Inc,.)

Dr. Jeongil Choi, earned his Ph.D. at the University of Nebraska, Lincoln in 2005. Currently he is an associate professor of MIS at Soongsil University, Seoul, KOREA. He also actively involves in Korean Broadcasting and Telecommunications-related policy issues.

Dr. Sang-Myung Lee, earns his Ph.D. at the University of Oregon in 2005 and currently an associate professor at Hanyang University, Seoul, KOREA. His research interests include strategic management in high-tech firms and entrepreneurship. 
International Journal of $u-$ and e- Service, Science and Technology Vol.9, No. 3 (2016) 